\title{
Cierpienie i strata w narracjach autobiograficznych
}

Streszczenie: Przedmiotem artykułu są żałoba i cierpienie jako tematy narracji autobiograficznej. Poprzez analizę narracji autobiograficznych opisujących cierpienie Autorka poszukuje odpowiedzi na dwa pytania. Pierwsze dotyczy formy i treści biografii cierpienia - w jakim stopniu są to narracje o specyficznej formie i treści i w czym można odnaleźć tę odmienność czy szczególność? Drugie pytanie towarzyszące Autorce artykułu to pytanie o wartość i znaczenie samego aktu ,spisywania cierpienia" dla biografii i rozwoju autorów takich autonarracji. Materiały, na których Autorka oparła swoje poszukiwania badawcze, to między innymi Dzienniki Virginii Wolf, literatura Agaty Tuszyńskiej, wspomnienia wojenne dzieci Holocaustu.

Słowa kluczowe: autobiografia, cierpienie, żałoba, rozwój całożyciowy.

\section{Suffering and loss as the autobiographical narrative}

Summary: The topic of article is mourning and suffering, as an autobiographical narrative themes. Through the analysis of autobiographical narratives, the author tries to answer two questions. The first concerns the form and content of the biography of suffering. The second question is a question about the value and importance of the act of ,writing of suffering” for biography and the development of authors such self-narration. Materials on which the author bases its research, among others, are Diaries of Virginia Woolf, Agatha Tuszyńska literature and memories of war children of the Holocaust.

Keywords: an autobiographical narrative, biography of suffering, longlife education.

* Górnośląska Wyższa Szkoła Handlowa im. W. Korfantego, Katedra Pedagogiki, 40-659 Katowice, ul. Harcerzy Września 3; urszula.tabor@gmail.com 
Opisać - to znaczy znów przeżyć, to znaczy znów w jakiś sposób przeżyć to, co było koszmarem. Nie opisać - to znaczy zapomnieć o tym, o czym ludzkość zapomnieć nie powinna.

Cyryla Szpan (1983, s. 256)

\section{Wstęp}

Przedmiotem artykułu jest temat straty, żałoby i cierpienia w autobiografii. Podejmując ten temat, byłam zainteresowana znaczeniem, jakie przeżyte cierpienie ma dla kreowanej narracji o cierpieniu. Dwa główne pytania, które stanowiły drogowskazy moich poszukiwań, to po pierwsze pytanie o formę i treść autobiografii pisanych w czasie doświadczania cierpienia (lub opisujących retrospektywnie taki czas w życiu autora). Pytanie to służyło zgłębieniu poszukiwań na temat tego, czy narracja cierpienia jest specyficzna oraz jaki wizerunek siebie kreuje autor takiej autobiografii. Drugi kierunek poszukiwań dotyczył biograficznego znaczenia, jakie może mieć pisanie (autobiografii) dla osoby będącej w żałobie, po stracie - czyli jaki biograficzny, całożyciowy sens ma dla autora opisywanie własnego cierpienia.

\section{Cierpienie, strata, żałoba}

Wśród wyróżnionych przeze mnie pojęć najogólniejszym jest pojęcie cierpienia. Intuicyjne, potoczne rozumienie cierpienia łączy się z poczuciem bólu, smutku, dyskomfortu, żalu, tęsknoty, braku, niezaspokojonym pragnieniem, brakiem nadziei, osamotnieniem, izolacją, napiętnowaniem, brakiem sił, przygnębieniem, lękiem.

Cierpienie obejmuje więc wielość stanów. Jeśli można je w jakiś sposób spróbować połączyć, to wspólną cechą tych stanów jest niezdolność lub trudność życia, „zadra” - uniemożliwiającą pełne wykorzystanie potencjału życia. Cierpienie jako doświadczenie człowiecze jest udziałem każdego w różnych momentach życia, co pozwala człowiekowi poznać jego smak i na przyszłość obawiać się go oraz unikać. Znaczenie i sens cierpienia jest tak samo istotnym tematem, jak znaczenie szczęścia - te dwa stany, nieuchwytne dla rozumu racjonalnego, wyznaczają drogi ludzkiego życia - wciąż dążymy do szczęścia, unikając cierpienia. Jednocześnie są swoimi niezbędnymi adwersarzami - pełne doświadczenie cierpienia i szczęścia jest udziałem tych, którzy zaznali tego drugiego. Toteż mimo bolesnych doznań płynących z cierpienia, doświadczanie go jest często etycznym wyznacznikiem rozwoju. Filozofowie podkreślają uszlachetniającą moc cierpienia, a etyka chrześcijańska wprost czyni cierpienie warunkiem koniecznym do pełnego rozwoju człowieczeństwa. 
Zainteresowanie cierpieniem i uzmysłowienie sobie różnych jego przejawów, doprowadziło człowieka do wyróżnienia specyficznych kategorii tego cierpienia. Wśród różnych obliczy cierpienia pewną grupę wspólną stanowią przeżycia związane ze stratą. Strata dotyka człowieka, który traci coś/kogoś, i zostaje wytrącony z normalnego rytmu życia, lub też odczuwa brak, głód, który nigdy dotąd nie był zaspokojony. Zatem strata łączy się z końcem jakiegoś wcześniejszego dobrostanu, jest niezaspokojoną tęsknotą za tym, co minęło. Żal, który jest efektem straty, nosi miano żałoby. Posługując się metaforą - na ziemi wyjałowionej utratą - zalega żałoba.

Zjawisko żałoby jest dobrze rozpoznane na gruncie psychologii, co pozwala współcześnie na precyzyjne opisy jego mechanizmów. Według Freuda doświadczenie żałoby należy odróżnić od melancholii. Żałoba ma być spowodowana utratą ukochanej osoby lub abstrakcji, jak ojczyzna, wolność. Nie jest zaskakująca, jest naturalnie wpisana $\mathrm{w}$ utratę $\mathrm{i}$ w ogólnym pojmowaniu nie należy jej leczyć ani w nią ingerować (Freud, 2007, s. 147). Freud thumaczy stan żałoby jako proces „odrywania”, „wycofywania” własnego libido z zaangażowania w innych. Jest to proces bolesny, budzący opór i czasochłonny, ponieważ wymaga restrukturyzacji własnego doświadczenia i odnalezienia substytutów zaangażowania. Ale zdaniem Freuda, ,ja” po przeprowadzeniu żałoby jest faktycznie wolne i niezahamowane (Freud, 2007, s. 148). Ilustrują to słowa Agaty Tuszyńskiej opisującej własny proces godzenia się z odchodzeniem męża: „H. żyje a ja uczę się śmierci. Studiuję śmierć, różne jej dotknięcia, objawy, przypadki. Obserwuję spustoszenia, jakie czyni. A potem uczę się od księdza Tischnera terminu «pustoszenie» jako klucza do doświadczenia braku, aktywnej agresywnej pustki śmierci” (Tuszyńska, 2007, s. 197).

Wracając do metafory wyjałowionej ziemi, żałoba chroni osobę przed dalszym zniszczeniem. Żałoba jawi się nie tylko jako akceptowalny element powrotu do zdrowia, ale także jako etap wręcz konieczny. Ziemia musi zostać przez chwilę „odłogiem”, człowiek musi mieć czas na wyrwanie ostatnich pędów łączących go z dawnym życiem, tkanka musi być oczyszczona i opłakana, aby mogło na niej wyrosnąć coś nowego. Zbyt szybkie sadzenie nowych roślin na zachwaszczonym zeschłą uprawą polu nie przyniesie dobrego plonu.

W tej perspektywie autonarracja cierpienia, może być ,narzędziem” żałoby, opowiadanie o cierpieniu służy bowiem uświadomieniu i nazwaniu tego, co się utraciło i jakie to miało znaczenie. Przeżycie o podobnym do żałoby obrazie, to opisana przez Freuda melancholia. Pod względem psychicznym wyróżnia się głębokim i bolesnym zniechęceniem, ustaniem zainteresowania światem zewnętrznym, utratą zdolności do kochania, zahamowaniem każdej sprawności, spadkiem samopoczucia, wyrażającym się w formie zarzutów i pretensji kierowanych pod własnym adresem, posuwającym się aż do obłędnego oczekiwania kary (Freud, 2007, s. 147). W tym zestawieniu proces żałoby jawi się jako psychologiczny mechanizm, niewykluczający, a nawet warunkujący powrót do zdrowia i dobrostanu psychicznego. Zaś melancholia jako stan chorobowy, współcześnie określany depresją, stan niesprzyjający rozwojowi i zdrowiu jednostki. O ile więc stan żałoby jest potrzebnym doświadczeniem po stracie, 
o tle depresję czy melancholię można postrzegać jako destrukcyjne dla osoby, ciągłe, uporczywe doświadczanie i przeżywanie straty, cierpienia.

Rozróżnienia powyższe są istotne z perspektywy narracji cierpienia, które wykorzystałam w swoich poszukiwaniach. Autonarracje pisane w żałobie mają nieco inną funkcję i konstrukcję niż narracje pisane w stanie permanentnej depresji. Ćwiczenia z utraty Tuszyńskiej noszą znamiona oswajania żałoby, jeszcze zanim doszło do straty, niektóre biografie dzieci holocaustu mają znamiona pożegnania z utraconym (dzieciństwem). Natomiast fragmenty Dzienników Wirginii Woolf ukazują obraz osoby niemal „zanurzonej” w całożyciowym cierpieniu ${ }^{1}$. Interesującą narracją jest Smutek C. S. Lewisa, który dokonuje introspekcji bólu, przygląda się ,na bieżąco" swojemu istnieniu w bólu, w ten sposób definiując, czym jest dla niego strata.

\section{Autobiografia jako gatunek}

Autobiografia w definicji Philippe'a Lejeune'a jest to „retrospektywna opowieść prozą, gdzie rzeczywista osoba przedstawia swoje życie, akcentując swoje jednostkowe losy, a zwłaszcza dzieje swej osobowości” (Michalski, 2010, s. 28). W definicji tej ukazują się trzy warstwy, które przyczyniają się z jednej strony do bogactwa tego gatunku, $\mathrm{z}$ drugiej - zamazują jego genealogię. $Z$ pewnością autobiografia jest określonym gatunkiem literackim, można więc ją analizować $\mathrm{z}$ tej perspektywy - biorąc pod lupę słowo jako środek wyrazu i pytając: jakie cechy gatunkowe ma autobiografia. Jednocześnie jest to literatura faktograficzna, co często czyni (auto)biografię niewolnicą faktów i chronologii. Ostatecznie jest studium psychologicznym człowieka, jego rozwoju i doświadczenia - a więc znosi wymóg obiektywności i jednoznaczności. Ponadto autobiografia jest, zdaniem Lejeune'a, nacechowana etycznie, ponieważ autor autobiografii zawiera z czytelnikiem pakt autobiograficzny, czyli swego rodzaju umowę o prawdziwości tego, co opisane w autobiografii. Pakt zobowiązuje autora do mówienia (pisania) prawdy, a zaufanie tej prawdzie sprzyja nawiązaniu między czytelnikiem a autorem swoistej relacji (Michalski, 2010, s. 30).

Istnienie takiego związku autora z czytelnikiem z pewnością sprzyja pisaniu i czytaniu autobiografii, kształtując klimat intymnej rozmowy i wzajemnego zrozumienia. Stan ten łatwo jednak zaburzyć, uświadamiając sobie, że, nawet mimo paktu ,autobiografia nie robi tego, co głosi” - to znaczy nie ukazuje prawdy o życiu autora (Michalski, 2010, s. 31). Przyczyną tego stanu rzeczy jest, jak pisze Łukasz Michalski, figuratywność języka, za którym kryje się doświadczenie, ale który doświadczenia nie jest w stanie wiernie powtórzyć, a jedynie odtworzyć (Michalski, 2010, s. 32). Jeśli zatem narzędzia językowe, jego symboliczność uniemożliwiają powtórzenie prawdy, to pozostaje jedynie „wczucie się” w świat kreowany przez autora.

${ }^{1}$ Jest znanym faktem biograficznym, że Virginia Woolf cierpiała na depresję i ostatecznie popełniła samobójstwo. 
Z perspektywy postawionego tematu warto zadać pytanie o przyczynę czytania autobiografii cierpienia? Wydaje się, że wśród tych, którzy czytają o cierpieniu - nie wiarygodność faktograficzna jest tym, czego się poszukuje, lecz możliwość przeżycia wraz z autorem określonych emocji. Zdzisław Cackowski pisze: „Lektura takich tekstów [tzn. tekstów o cierpieniu - przyp. U. T.] jest zawsze (inaczej być nie może) odczytywaniem własnych bolesnych doświadczeń i nadawanie tym doświadczeniom [...] jego własnej intelektualnej /teoretycznej formy" (Cackowski, 1997, s. 33).

Pytanie istotne z punktu postawionego tematu brzmi: jaką funkcję pisanie autobiografii pełni w procesie przeżywania cierpienia i żałoby? Z pewnością nie jest to funkcja dokumentacyjna. Nie można też uznać, że autobiografia thumaczy, czy dzieli z czytelnikiem świat, w którym jest zanurzony autor. Jak celnie zauważa Ł. Michalski, autobiografia nie jest tym, za co się podaje. A więc nie opisuje świata podmiotu, ale go nazywa słowami podmiotu. Z perspektywy dokumentarnej jest to problem metodologiczny. Natomiast z perspektywy terapeutycznej - jeśli pisanie uznać za narzędzie terapii - nie ma to znaczenia, że światy konstruowane nie odzwierciedlają rzeczywistych, a raczej, że odzwierciedlają je w zniekształceniu. Można zadać pytanie: jakie znaczenie dla osoby piszącej o własnym cierpieniu ma to, aby historia była jak najbliższa faktom? Oraz dalej - jakie znaczenie ma, aby historia opowiadała precyzyjnie o przeżyciach? Przeżycia nie są bowiem faktami, ale są ich pochodnymi. A więc autobiografia faktograficzna i „wglądowa" (mam tu na myśli analizę i opis własnych emocji) będą się z pewnością różniły - jedna będzie pisana „z zewnątrz”, druga „od wewnątrz”.

\section{Cierpienia a autobiografia}

\section{Dzieci holocaustu: żałoba po dzieciństwie}

„Pytanie, które mnie tutaj interesuje [...] to pytanie o życiodajną moc traumatycznych wspomnień, o to w jakim stopniu widma urazowej przeszłości dają się wykorzystać rozwojowo", pisze Krzysztof Maliszewski w swoim studium o zranionej pamięci (Maliszewski, 2010, s. 58). W cytowanym tekście Autor pyta, czy ciężar traumy można wykorzystać dla dobra rozwoju i ostatecznie konkluduje o takiej możliwości. Taka konkluzja wymaga tyleż optymizmu, ile nadziei i wiary, że doświadczenia cierpienia są dla człowieka uszlachetniające, nie zaś erozyjne czy degenerujące. Myślę, że raz jeszcze należy rozważyć to pytanie, nie pozwalając sobie zbyt pochopnie na pokrzepiające odpowiedzi. Interesujące jest długoterminowe działanie pamięci cierpienia. A więc nie tyle suma pozytywnych czy negatywnych zdarzeń życiowych jest interesująca, ale reperkusje tychże zdarzeń na losy jednostki. Jak funkcjonuje „pamięć cierpienia” i jak kształtuje ona biografię?

„W tradycyjnych mitach zapomnienie jest równoznaczne ze śmiercią $[\ldots]$ dlatego utrata wspomnień zawsze jest w pewnym stopniu zanikaniem tożsamo- 
ści" (Maliszewski, 2010, s. 59). W tym sensie narracja cierpienia jest bolesnym warunkiem zachowania tożsamości, unikanie pamięci straty byłoby uśmiercaniem własnej wrażliwości w ogóle. Niechcianą konsekwencją amnezji jest bowiem postawa lękowa i niezdolność do dialogu (ibidem). Nie sposób przecież dokonać selekcji i uniewrażliwić się tylko na wybrane doświadczenia, zamrozić smutek, żal i złość, to skazać się na niewrażliwość wobec radości, wzruszenia, nadziei. Wobec tego - pamięć straty, choć dotkliwa, wydaje się konieczna dla zachowania ciągłości rozwoju, nawet osobę wzbogaca, choć koszty tego postępu są ogromne. Ponadto - nie każdy rodzaj straty i cierpienie nosi taki uszlachetniający rys, a także - nie w każdej traumie można odnaleźć jakiś moralny walor.

O ile żałoba - jak pisał Freud - jest procesem powrotu do zdrowia po stracie określonej relacji, o tyle istnieją takie cierpienia, które trwają, a ich nieskończoność wynika z braku uzasadnienia dla tego cierpienia. Maliszewski pisze: „przeszłość jest nieodwracalna, ale nie jest nieodwracalny jej sens. Jeśli w istocie fakty nie dają się zatrzeć i jeśli nie może się odstać to, co już się stało, ani nie można sprawić, żeby to, co się zdarzyło, nie zdarzyło się, to jednak sens tego, co się zdarzyło, nie jest ustalony raz na zawsze" (Maliszewski, 2010, s. 68). W słowach tych pobrzmiewa nadzieja, a jednocześnie trudno się wyzbyć wrażenia, że jest to próba usensownienia tego, w czym trudno znaleźć sens. Jakby nadanie nawet nowego sensu cierpieniu czyniło je logicznym. Zdzisław Cackowski również zwraca uwagę na to, jak istotny dla przeżywania cierpienia jest jakiś jego instrumentalny sens: „[...] cierpienie, co do którego nie ma żadnej nadziei, że czemuś lub komuś może służyć [...], takie cierpienie nie niesie ze sobą żadnej pocieszycielskiej treści, żadnego usprawiedliwiającego i przez to niosącego jakąś ulgę sensu" (Cackowski, 1997, s. 94). W kontekście tych słów szczególnie brzmią narracje autobiograficzne „dzieci holocaustu”. I o ile niektóre biografie bólu, żałoby i straty można uznać za literacką próbę zrozumienia i dookreślenia cierpienia, o tyle w przypadku holocaustu byłaby to próba zbyt perwersyjna. Niektóre narracje wprost mówią o braku sensu, i związanym z tym bólem niepogodzenia. Maria Terlecka, malarka, pisała: „Jestem plastyczką. I to co robię [...], jest nierozerwalnie związane z okresem złym i okrutnym. Byłam dzieckiem w czasie wojny i moja pamięć tamtych dni jest stertą strzępów. Wyciągam kawałki zdarzeń i sytuacji i przetwarzam je na obrazy. Jest to obsesja. Wyrzucanie złości. Wypędzanie wojny. Przepędzanie czarownic [...]. Usiłuję pozbyć się wojny, ale nie mogę. Przychodzi czasami w nocy, a tego bardzo nie lubię" (Terlecka, 1983, s. 22).

Z. Cackowski pisze „Cierpienia ludzi zadawane im przez hitlerowców to były cierpienia intencjonalne, mające sens - zbrodniczy sens. Ale tych cierpień nie wolno, nie wolno z moralnych względów wpisywać w plan boskiego stworzenia" (Cackowski, 1997, s. 95).

Można więc postawić tezę, że część autobiografii cierpienia służy poszukiwaniu sensu własnych bolesnych doświadczeń, który będzie zadośćuczynieniem. Ale wiele historii pozostaje poza argumentami ludzkiej logiki. Wówczas autobio- 
grafie te przyjmują charakter świadectwa, przestrogi (co też ostatecznie w jakiś sposób je usensownia) i dzięki temu pozwala zaakceptować jako część własnego doświadczenia. Cackowski pisze: „Każde cierpienie prędzej czy później, tak czy inaczej się kończy [...]. Jednakże to, co zostało przecierpiane, jakoś pozostaje i trwa: jako wspomnienie i pamięć, jako przestroga, czyli motyw działania, jako czujność i wiadomość. Inaczej mówiąc, to co przecierpiane staje się elementem ludzkiej [...] podmiotowości, jej instrumentalnym wyposażeniem" (Cackowski, 1997, s. 95-96).

Tam gdzie narrator nie doszukuje się przyczyn cierpienia, lecz wprost relacjonuje ,przebieg” własnego cierpienia, pojawiają się opisy niemal sprawozdawcze. Znalazłam takie zapisy w Dziennikach Wirginii Woolf, a także w niektórych relacjach dzieci holocaustu. W niektórych dziecięcych wojennych autonarracjach najbardziej okrutne sceny są opisane ze spokojem, spokojem oczywiście pozornym. Wynika on zapewne z niemożliwości dziecka do realnej oceny sytuacji, albo też jest efektem psychologicznego mechanizmu określanego jako zaburzenie dysocjacyjne. Zaburzenie dysocjacyjne polega na zakłóceniu integracji funkcji pamięci, świadomości i tożsamości. [...] Dysocjacja jest procesem oddzielania się jednostki od tego, co się z nią dzieje podczas zdarzenia traumatycznego, od swoich doznań (Jagodzińska, 2008, s. 489 i nast.). Stella Władymirowna, więźniarka obozu w Ravensbruck, gdzie trafiła w wieku 2-3 lat, tak opisuje śmierć matki: „Potem już nigdy mamy nie widziałam, ale wierzyłam, że jest na rewirze [...] aż do czasu, kiedy przy wejściu do baraku Klara [...] powiedziała mi: Stella, twoją mamę spalili. Przyjęłam to zupełnie spokojnie [...] Czy to nie uwierzyłam, czy też tak często słyszałam o krematorium, że już na to nie reagowałam. [...] Oczywiście, po prostu nie rozumiałam sensu tego strasznego słowa «spalili»... Miałam przecież wtedy tylko 5 lat. I zrozumiałam nieprędko" (Władymirowna, 1983, s. 34). Autorka przyznaje dalej, że dopiero z czasem zrozumiała swój dramat i zaczęła go opłakiwać. A zatem w biografiach dzieci wojennych pisanie autobiografii służy raczej przestrodze, upomnieniu się o uwagę, niż doszukiwaniu się sensu w ówczesnych traumatycznych wydarzeniach. Żałoba wojennych sierot to opłakiwanie niespełnionego, tęsknota za dobrymi wspomnieniami, które zastąpiło piekło wojny. Elżbieta Krajewska pisała: „Trudno to nazwać dzieciństwem. Jak tylko sięgnę pamięcią wstecz, uświadamiam sobie, że moi kompani w dzieciństwie to głód, strach, poniewierka i poniżenie. Moje dziecięce marzenia nigdy się nie spełniły [...]. Wojna i okupacja nie tylko zabrały mi dzieciństwo, lecz pozostawiły ślady na mojej psychice" (Krajewska, 1983, s. 69).

Żałoba po dzieciństwie jest tym dotkliwsza, że nie ma możliwości zastąpienia tego okresu życia innym, nie ma substytutu. Jest to utrata totalna - czegoś, co nigdy się nie zaczęło i pogwałcenie niewinności dziecka dorosłymi doświadczeniami. Bardzo poruszająco pisze o tym Ludmiła Niedbalska: „Wciąż te sprawy tkwią w nas, przynajmniej we mnie, a przecież nie jestem nikim wyjątkowym. Uważam nawet, że los obszedł się ze mną i moimi najbliższymi dość oszczędnie. 
Ale chciałabym odpowiedzieć na często słyszane pogardliwe nieco pytanie: «Co Ty możesz wiedzieć o wojnie, byłaś wtedy za mała». Za mała - na co? Dla Niemców nie byliśmy za mali na nic. A co trzeba wiedzieć, kiedy się leży pod gruzami czteropiętrowej kamienicy? A może coś trzeba wiedzieć, żeby tego nie pamiętać? Może ktoś mi na to pytanie odpowie?..." (Niedbalska, 1983, s. 104).

Słowa te wskazują na jeszcze jedną istotną funkcję wspomnień - autorka broni się przed trywializacją jej przeżyć. Kiedy pojawiają się wątpliwości co do autentyczności czyichś wspomnień lub pomniejsza się ich wagę (np. dzieci), prowadzi to wprost do kwestionowania prawa do cierpienia i prawa do czucia. Wydaje się, że jest to istotny rys autobiografii pisanych w żałobie i w cierpieniu w ogóle. Opisanie bólu i straty być może wzbogaca percepcję samego Autora i jego publiczności, dając dokładny, słowny opis cierpienia, Autor chroni się przed ulotnością i strywializowaniem bolesnych przeżyć.

\section{Ćwiczenia z utraty: pożegnania z najbliższym Agaty Tuszyńskiej i C. S. Lewisa}

Jak pisze K. Maliszewski: „pamięć traumy nie dając się łatwo oswoić, dokonując nieustannej inwazji obcości w uładzony porządek rutyny i oczywistości - może chronić życie duchowe przed letargiem" (Maliszewski, 2010, s. 62).

Jakie znaczenie ma ta teza o „poruszającej mocy” cierpienia dla pisania autobiografii? Książka Smutek C. S. Lewisa zdaje się potwierdzać tę tezę. Lewis, opisujący własne zmagania z bólem po stracie żony, dokumentuje swoje moralne $\mathrm{i}$ intelektualne wytrącenie $\mathrm{z}$ tego, co dotychczas było pewne i niezaprzeczalne. Wraz z kolejnymi próbami zrozumienia sensu śmierci żony dochodzi do pytań generalnych - np. o to, czy i jak: świat i on sam w ogóle istnieją: „Rzeczywistość gdy przyjrzeć się jej uważnie jest nie do zniesienia. Jak i dlaczego taka rzeczywistość rozwinęła się (i rozpadła) w straszne zjawisko zwane świadomością. [...] Jeśli H. nie ma, to nie było jej nigdy. Wziąłem kłębek atomów za żywą istotę. Nie ma i nigdy nie było żadnych ludzi. Śmierć odsłania jedynie pustkę, która zawsze istniała zamiast nich" (Lewis, 2009, s. 55).

Także Ćwiczenia z utraty Agaty Tuszyńskiej to opis potwierdzający, że cierpienie wymaga nowego, wymaga przystosowania. Jest wytrąceniem z rutyny i pewności. Pisarka, opisując rok życia przy boku ukochanego umierającego męża, wielokrotnie stawia granice między tym, co było a co jest: „Twój problem polega na tym - mówi Ewa S. - że starasz się go traktować jak zdrowego, jak przedtem, jakby choroba była przeszłością. Tak nie jest. Nie jestem tym samym H. sprzed diagnozy. Tamtego nie ma. Nie ma" (Tuszyńska, 2007, s. 164). Sam tytuł dziennika Tuszyńskiej tłumaczy jego formę i treść, ponieważ są to „małe ćwiczenia na temat utraty", opisy kolejnych dni, kiedy Autorka, rzec można, 
„kształtuje kondycję” w utracie. Zapiski codziennych czynności, rozmów z mężem przeplatają się z fragmentami wspomnień. Dziennik Tuszyńskiej jest opowieścią o pożegnaniu. Sama jednak na wstępie podkreśla: „Tego nie można dotknąć słowem, myślałam. Po raz pierwszy odkąd pamiętam, SŁOWO jest bezsilne. Jest odklejone od rzeczywistości, jaką miałoby ogarnąć, której mogłoby lub miałoby nieść ulgę. Nie władam już słowem. Nie sprawdziło się. Rozpacz nie zna słów" (Tuszyńska, 2007, s. 6).

Mimo to Tuszyńska pisze dalej: „Nie mam wyjścia. Mogę pisać albo oszaleć. Pisać. Zawalczyć o siebie, jak radzą przyjaciele. [...] Znowu nie przestaję rozstawać się z piórem i zeszytem" (Tuszyńska, 2007, s. 165). Czy tę potrzebę opowiadania bólu, mimo poczucia niemożności wydobycia głosu, można wytłumaczyć niechęcią dla zapomnienia? Adam Głowacki pisze: „Pamięci ufać nie można, ponieważ na pamięci dokonuje się dodatkowych operacji, codziennie, co chwilę" (Głowacki, 2010, s. 85). Jednocześnie słowa te można uznać za przyczynę i motywację pisania autobiografii w ogóle, a także autobiografii cierpienia, jeśli doświadczenie ma pozostać udokumentowane, nie może być to jedynie ulotne archiwum pamięci.

A jednak pisanie autobiografii w bólu, w celu poznania i dookreślenia tego bólu wydaje się przedsięwzięciem nieudanym. Autobiografia jest bowiem wycinkiem życia, domyka jakiś jego okres, zaś proces reinterpretowania bólu jest nieskończony. Biografia nie jest w stanie udźwignąć dynamiki tego rozwijającego się procesu, który sama napędza, pisanie o bólu jest kluczem do kolejnych szuflad ze znaczeniami cierpienia. Lewis opisuje to zjawisko w końcowej części Smutku „Te notatki jako swego rodzaju obrona przed kompletnym załamaniem i klapa bezpieczeństwa spełniły jakąś dobrą rolę. Inny cel, który miałem na uwadze okazał się oparty na nieporozumieniu. Myślałem, że potrafię opisać jakiś stan, narysować mapę smutku. A tymczasem smutek to nie stan lecz proces. Nie wymaga mapy, ale historii, i jeżeli nie przestanę opisywać tej historii w dowolnie obranym momencie, nie ma powodu bym kiedykolwiek zaprzestał" (Lewis, 2009, s. 97).

\section{Dziennik Virginii Woolf: zanurzenie w cierpieniu}

K. Maliszewski, w ślad za Timothym Radcliffem, przestrzega przed umieszczaniem krzywdy w centrum tożsamości - przywołuje także słowa Arno Mayera, że „świat jest mniej straszony «widmem człowieka bez pamięci» niż widmem człowieka bez zapomnienia" (Maliszewski, 2010, s. 60).

Warto rozważyć ten postulat w odniesieniu do krzywdy przewlekłej, do cierpienia permanentnego, które właśnie czyni krzywdę rdzeniem tożsamości. Mam tu na myśli percepcję cierpienia przez osoby chorujące przewlekle lub cierpiące na depresję. 
Przeżycia Virginii Woolf noszą znamiona przewlekłego cierpienia, depresji, którą Freud określał jako melancholię. Pisał, że „melancholia często nie pozwala uświadomić sobie obiektu straty, a nawet wiedząc co utraciła, osoba cierpiąca nie wie co to dla niej znaczy" (Freud, 2007, s. 149). Melancholia jest także tym rodzajem cierpienia, które, zdaniem Freuda, zuboża własne ,ja”. W wypadku żałoby to świat zubożał i opustoszał - w wypadku melancholii zubożało i opustoszało samo „ja”. Chory opisuje siebie jako osobę niepełną, niegodną, oczekuje odrzucenia i kary, ubolewa nad innymi, którzy są z nim związani, nie uważa, że zaszła w nim jakaś niekorzystna zmiana, lecz rozciąga krytykę siebie na przeszłość, uznając, że zawsze był niedoskonały (Freud, 2007, s. 149). W tym ujęciu depresja jest stratą samego siebie, a więc dokumentowanie depresji w postaci, w jakiej czyni to Woolf, jest opisywaniem smutku wynikającego z samego ,ja”: „Sobota, 20 marca. Co takiego ma wyniknąć z tego dziennika [...] Jeślibym umarła, co Leo z nim zrobi? [...] Hm, pewnie wykroi z nich książkę, a potem całość spali [...]. Takie myśli dyktuje mi lekka melancholia, która dopada mnie teraz od czasu do czasu i każe mi stwierdzać, że jestem stara, brzydka i że się powtarzam. A jednak z tego co wiem, to jako pisarka dopiero teraz naprawdę zaczęłam spisywać swoje myśli”.

Mimo że Woolf cierpiała na depresję przez całe życie i wielokrotnie doznała poważnych załamań nerwowych, w Dzienniku obejmującym ponad 25 lat życia opisy depresji, smutku są nieczęste, jakby przypadkowe i sprawozdawcze: „Sobota, 31 lipca 1926. Oto załamanie nerwowe w miniaturze. Przyjechaliśmy we wtorek. Zapadłam w fotel i niemal nie mogłam się zeń podnieść; wszystko mdłe; bez smaku, bez koloru. Przemożne pragnienie wypoczynku. Środa - jedno życzenie: być samej na wolnym powietrzu. Powietrze cudowne - unikam mówienia, nie mogę czytać. $Z$ nabożeństwem myślę o swoich siłach twórczych jako o czymś niewiarygodnym, należącym do kogoś innego; czego ja sama już nigdy nie zaznam. Pustka w umyśle. Spanie w fotelu. Czwartek. Żadnej przyjemności z życia, ale może troszkę więcej nastawienia na bycie. Charakter i cechy szczególne Virginii Woolf kompletnie zanikły. Pokora i skromność, trudności z wymyśleniem co powiedzieć. Czytanie automatyczne, jak krowie przeżuwanie. Spanie w fotelu. Piątek. Poczucie fizycznego zmęczenia, ale jakby delikatne poruszenia umysłu [...] Sobota (dzisiaj) o wiele czystsza i jaśniejsza. Myśl, że być może jestem w stanie pisać, ale odrzucona lub uznana za niewiarygodną [...]" (Woolf, 2007, s. 307).

Opisy depresji przeplatają się z opisami codziennych czynności, wizyt, swoich spraw zawodowych. Nie poświęca swemu smutkowi Woolf jakiegoś szczególnego miejsca, nie rozważa nad jego sensem. Prawie udaje jej się „zmylić” czytelnika, że nie doświadcza większych cierpień, gdy nagle zamieszcza wpis w dzienniku, jak ten z 15 września 1926 r.: „Obudziłam się chyba o trzeciej. O, zaczyna się, nadchodzi - strach - fizycznie, jak bolesna fala wzbierająca wokół serca, wyrzucająca mnie w górę. Jestem nieszczęśliwa, nieszczęśliwa! Świt - Boże, chciałabym nie żyć [...]. Przyjrzę się tej wzbierającej fali. Przyglądam się. Vanessa. Dzieci. Klęska. Tak, wytropiłam to. Klęska. Klęska. (Fala się wznosi). 
O, śmiali się z mojego zamiłowania do zielonej farby! Fala uderza. Chciałabym nie żyć. Mam nadzieję, że przede mną już tylko kilka lat. Nie jestem już dłużej w stanie znosić tego strachu - (teraz mnie fala zalewa). I tak to trwa, parę razy, różne odmiany strachu [...]" (Woolf, 2007, s. 309).

Jaki jest więc cel pisania o takim cierpieniu, skoro Autorka nie szuka w nim sensu, nie wyróżnia go z codzienności, nie czyni przestrogą? Prawdopodobnie sama Woolf nigdy nie określiłaby swojego Dziennika jako biografii cierpienia. Być może permanentna obecność stanu cierpienia dla samej Autorki uczyniła temat „niespecyficznym”, nieodłącznym od tego, jakie jej życie było i miało być. Lecz i taki wniosek nie przekreśliłby faktu, że jej Dzienniki dla czytelnika są osobistym opowiadaniem na temat smutku i cierpienia.

Każdy z nas jest opowiadaniem, opowiadaniem, które wciąż nieświadomie piszemy - piszemy naszym postrzeganiem, uczuciami, myślami, działaniem, i, co nie jest bynajmniej błahe, naszymi rozmowami, przekazywaniem innym tego opowiadania (Sacks, 1996).

\section{Zakończenie}

„Każde cierpienie prędzej czy później, tak czy inaczej się kończy [...]. Jednakże to, co zostało przecierpiane, jakoś pozostaje i trwa: jako wspomnienie i pamięć, jako przestroga, czyli motyw działania, jako czujność i świadomość. Inaczej mówiąc, to co przecierpiane staje się elementem ludzkiej [...] podmiotowości, jej instrumentalnym wyposażeniem" (Cackowski, 1997, s. 95-96).

Przedmiotem artykułu były poszukiwania w obszarze tychże właśnie jednostkowych interpretacji sensu cierpienia oraz specyficznych cech autonarracji cierpienia. $\mathrm{W}$ tych poszukiwaniach ukazały się pewne płaszczyzny różnicujące interpretację i opis cierpienia.

Po pierwsze w różny sposób jawi się motywacja do pisania o własnym cierpieniu. Jedną z motywacji do pisania o bolesnych doświadczeniach jest potrzeba, aby nadać sens cierpieniu, które jest bezsensowne.

Wspomnienia autobiograficzne niejednokrotnie służą „napomnieniu”, ,pouczeniu", autor biografii dzieli się opisem własnego cierpienia, po to, by przestrzec innych. I znowu można zadać pytanie, czy humanistyczna pobudka - ochrony innych nie jest zabarwiona potrzebą nadania własnemu cierpieniu sensu? Być może namiastką tego sensu będzie wiara, że „dzięki mojej historii” coś podobnego już się nie wydarzy. Anna Jacyna-Janc pisała: „Nikt nie jest w stanie zliczyć ani zmierzyć cierpień, będących „ubocznym skutkiem” przeżyć okupacyjnych [...]. Dlatego trzeba pisać i przypominać tym, którzy chcą zapomnieć o naszych cierpieniach i okrucieństwach wojny, aby nie tylko zapobiec nowej wojnie, lecz także by nie dopuszczać do jakiejkolwiek postaci okrucieństwa między ludźmi” (Jacyna-Janc, 1983, s. 222). 
Motywacją do opisywania własnego bólu może być także potrzeba uzyskania poczucia kontroli nad cierpieniem, poczucie, że się cierpienie rozumie i przewiduje. Takie narracje odnajdujemy w Dziennikach Virginii Woolf, w pisarstwie Agaty Tuszyńskiej. Pisanie może być motywowane chęcią opowiedzenia sobie i innym, tego, co niemożliwe (do wyrażenia), jak to robi C. S. Lewis. To wiąże się z pewnością z potrzebą uchronienia bolesnych wspomnień od zapomnienia - a więc narracje cierpienia pisane są także, aby nie zapomnieć i nie pozwolić utracić tej pamięci innym (bo wtedy bolesne doświadczenie zostaje strywializowane). Ostatecznie każdy opis cierpienia w sposób zamierzony lub nie prowadzi Autora do samowiedzy w zakresie własnych reakcji i sposobów radzenia sobie z sytuacją cierpienia.

Na zakończenie interesujące może być także podkreślenie dwóch typów autonarracji cierpienia, które dość wyraźnie ujawniają się w cytowanych tekstach: są to opisy sensu i opisy faktu. Tam, gdzie można nadać cierpieniu jakiś sens (co z pewnością ułatwia włączenie go w doświadczenie biograficzne), opis jest refleksją nad sensem cierpienia, na przykład nad jego wartością uwrażliwiającą. Natomiast w tych sytuacjach, gdy autor nie może lub nie potrafi odnaleźć sensu cierpienia, jego opis staje się sprawozdawczy, faktograficzny, dokumentarny. W ten sposób narracja cierpienia jest jak zeznanie świadka, który poszukuje sprawiedliwości, albo przynajmniej pragnie innych świadków, jako tych, którzy uchronią cierpienie przed zapomnieniem.

\section{Literatura}

Cackowski Z., Ból, lęk, cierpienie. Kategorie ludzkiego doświadczenia, Wydawnictwo UMC-S, Lublin 1997.

Freud Z., Żałoba i melancholia, [w:] Psychologia nieświadomości, przeł. R. Reszke, Wydawnictwo KR, Warszawa 2007.

Głowacki A., 2010, Pamięć, która kłamie, [w:] J. Kurek, K. Maliszewski (red.), Widma pamięci, Medium Mundi $V$, Chorzów.

Jacyna-Janc A., 1983, Trwate ślady - dalsze cierpienia, [w:] Dzieciństwo i wojna, Ankieta „Życia Warszawy" - wspomnienia czytelników, Czytelnik, Warszawa.

Jagodzińska M., 2008, Psychologia pamięci. Badania, teorie, zastosowania, Wydawnictwo Helion, Gliwice.

Krajewska A., 1983, Liczyłam dni i godziny, [w:] Dzieciństwo i wojna, Ankieta „Życia Warszawy” - wspomnienia czytelników, Czytelnik, Warszawa.

Kurek J., Maliszewski K. (red.), 2010, Widma pamięci, Medium Mundi V, Chorzów.

Lewis C. S., 2009, Smutek, Wydawnictwo Esprit, Kraków.

Maliszewski K., 2010, Zraniona pamięć - życiodajna moc widma, [w:] J. Kurek, K. Maliszewski (red.), Widma pamięci, Medium Mundi VI, Chorzów.

Michalski Ł., 2010, Demon autobiografii, [w:] J. Kurek, K. Maliszewski (red.), Widma pamięci, Medium Mundi VI, Chorzów. 
Niebalska L., 1983, Bóg na urlopie, [w:] Dzieciństwo i wojna, Ankieta „Życia Warszawy” - wspomnienia czytelników, Czytelnik, Warszawa.

Sacks O., 1996, Mężczyzna, który pomylit swoją żonę z kapeluszem, przeł. B. Lindenberg, Wydawnictwo Zysk i S-ka, Poznań.

Szpan C., 1983, Opisać, to znaczy znów przeżyć, [w:] J. Mazurczyk, K. Zawanowska, Dzieciństwo i wojna, Ankieta „Życia Warszawy” - wspomnienia czytelników, Czytelnik, Warszawa.

Terlecka M., 1983, Obrazy, [w:] Dzieciństwo i wojna, Ankieta „Życia Warszawy” - wspomnienia czytelników, Czytelnik, Warszawa.

Tuszyńska A., 2007, Ćwiczenia z utraty, Wydawnictwo Literackie, Kraków.

Władymirowna S., 1983, Znałam tylko swoje imię, [w:] Dzieciństwo i wojna, Ankieta „Życia Warszawy" - wspomnienia czytelników, Czytelnik, Warszawa.

Woolf V., 2007, Chwile wolności. Dziennik 1915-1941, przeł. M. Heydel, Wydawnictwo Literackie, Kraków. 